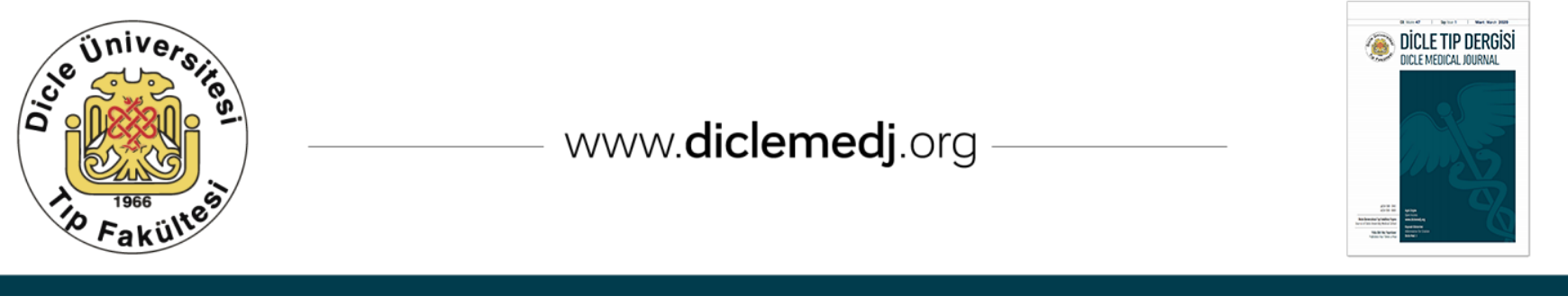

Original Article / Özgün Araştırma

\title{
Is HbA1c Misleading and 90-Minute Glucose Tolerance Test a Better Indicator in the Diagnosis of Diabetes Mellitus?
}

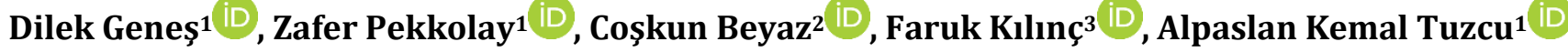 \\ 1 Dicle University Faculty of Medicine, Department of Adult Endocrinology and Metabolism, Diyarbakir Turkey \\ 2 Mersin City Hospital, Department of Adult Endocrinology and Metabolism, Mersin Turkey \\ 3 Firat University Faculty of Medicine, Department of Adult Endocrinology and Metabolism, Elazig Turkey
}

Received: 25.12.2019; Revised: 26.02.2020; Accepted: 27.02.2020

\begin{abstract}
Objective: The present study aimed to investigate the efficacy of hemoglobin A1c (HbA1c) in diagnosing type 2 diabetes and to introduce a new approach to oral glucose tolerance test (OGTT).

Methods: This retrospective cross-sectional study included 560 subjects (363 females, 197 males) with a mean age of $46.7 \pm 12.9$ years. These subjects underwent a standard 75-g OGTT, plasma glucose levels were assayed at 0, 30, 60, 90, and 120 minutes in 232 subjects who consented to these tests, and the area under the curve (AUC) was calculated. HbA1c levels were also measured simultaneously. The receiver operating characteristics (ROC) curve was used to determine the sensitivity and specificity of certain HbA1c cut-off values in diagnosing diabetes in subjects who underwent OGTT. Chisquare test was used for data comparisons, and Pearson's correlation coefficient was used to evaluate the relationship between the measurements.
\end{abstract}

Results: Among the 560 subjects, 129 had diabetes and 40 of the 232 subjects who were frequently tested for glucose levels had diabetes. The sensitivity and specificity of the HbA1c cut-off value of $6.5 \%$ in diagnosing diabetes were $55.0 \%$ and $80.9 \%$, respectively. The highest correlation was observed between the glucose level at 90 minutes and AUC and HbA1c ( $r=0.971, \mathrm{P}<0.01 ; \mathrm{r}=0.464, \mathrm{P}<0.01$, respectively).

Conclusion: An HbA1c cut-off value of 6.5\% had low sensitivity and specificity in diagnosing diabetes. The plasma glucose level at 90 minutes in subjects had the best correlation with both AUC and HbA1c, indicating that using plasma glucose level at 90 minute is a better approach for diagnosing diabetes.

Keywords: Diabetes Mellitus, HbA1c, glucose tolerance test, plasma glucose at 90 minutes

DOI: 10.5798/dicletip.706051

Correspondence / Yazışma Adresi: Zafer Pekkolay, Dicle University Faculty of Medicine, Department of Adult Endocrinology and Metabolism 21280,

Diyarbakir Turkeye-mail: drpekkolay@gmail.com 


\section{Diyabetes Mellitus Tanısında Hba1c Yanıltıcı, Glukoz Tolerans Testinde Doksan'ıncı Dakika Daha İyi Bir Belirteç Midir?}

Öz

Amaç: Bu çalışmadaki amaç tip 2 diyabet tanısında HbA1c'nin yararlılığını araştırmak ve oral glukoz tolerans testine yeni bir bakış getirmektir.

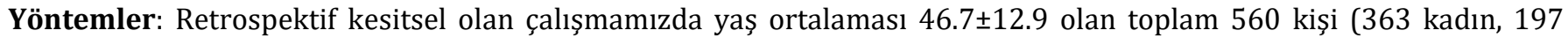
erkek) çalıșmaya dahil edildi. Bu kişilere standart $75 \mathrm{~g}$ oral glukoz tolerans testi (OGTT) yapıldı; ayrıca bunlar içerisinden kabul eden 232 kişide 0, 30, 60, 90 ve 120. dakikalarda plazma glukoz düzeyleri bakıldı ve Area Under Curve (AUC) değeri hesaplandı. Test ile eş zamanlı olarak HbA1c düzeyleri ölçüldü. OGTT yapılan bireylerde diyabet tanısında HbA1c'nin belirli kesim noktalarındaki sensitivite ve spesifitelerini belirlemek için Receiver Operating Characteristic (ROC) eğrisi kullanıldı. Şeker yüklemesinde hangi saatteki glukoz düzeyinin HbA1c ve AUC ile daha iyi korelasyon gösterdiği araştırıldı. Verilerin karşılaştırılmasında ki kare testi, ölçümler arasındaki ilişki için Pearson korelasyon testi kullanıldı.

Bulgular: 560 kişiden 129 kişi, bunlar içerisinde sık aralıklı glukoz bakılan 232 kişiden 40 kişi diyabetti. Diyabet tanısında HbA1c \%6,5 kesim noktası ile sensitivite \%55,0, spesifite \%80,9 bulundu. En yüksek korelasyon 90 . dakikadaki plazma glukoz değeri ile AUC ve HbA1c arasında görüldü (sırasıyla $\mathrm{r}=0.971 / \mathrm{P}<0.01 ; \mathrm{r}=0.464 / \mathrm{P}<0.01$ ).

Sonuç: HbA1c \%6,5 kesim noktası ile diyabet tanısında düşük sensitivite ve spesifite göstermiştir. 90. dakika plazma glukoz değeri hem AUC hem de HbA1c ile en iyi korelasyon gösterdi, bu nedenle diyabet tanısı konulmasında 90. dakika plazma glukozu bakılması daha uygun bir yaklaşım gibi görünmektedir.

Anahtar kelimeler: Diyabetes Mellitus, HbA1c, oral glukoz tolerans test, 90. dakika plazma glukozu.

\section{INTRODUCTION}

Diabetes Mellitus is a metabolic disease characterized by hyperglycemia secondary to an impairment in insulin secretion, insulin effect, or both ${ }^{1}$. Diabetes Mellitus can be diagnosed using fasting plasma glucose (FPG), plasma glucose at 2 hours in 75-g OGTT, or hemoglobin A1c (HbA1c) criteria. HbA1c reflects the average glycemic status over approximately 3 months and is a strong predictor of diabetic complications ${ }^{2}$; it is a relatively more stable parameter that does not require fasting 3 . In 2009, the International Expert Committee recommended the use of HbA1c in diagnosing diabetes ${ }^{4}$. Moreover, American Diabetes Association (ADA) approved the use of HbA1c in diagnosing diabetes in 2010. It was recommended to use $\mathrm{HbA1c}$ by employing a traceable method that has been approved by the National Glycohemoglobin Standardization Program and standardized according to the Diabetes Control and
Complications Trial reference test ${ }^{5}$. However, $\mathrm{HbA1c}$ is an indirect measure of glycemic status and, therefore, has limitations. Alterations in erythrocyte cell cycle (hemoglobinopathies, hemolytic and other anemias, recent blood transfusion, use of erythropoiesis stimulating drugs, end-stage renal disease, and pregnancy) may cause inconsistencies between HbA1c results and the actual average glycemic status ${ }^{2}$.

To date, there is no consensus on the most accurate screening test for type 2 diabetes $^{6}$. Moreover, the most suitable HbA1c cut-off value in diagnosing diabetes remains controversial considering that the sensitivity varies according to ethnicity ${ }^{7}$. Several clinical conditions can affect the accuracy of the test and produce false results of high or low HbA1c. The most significant concern is the assessment of false results of low HbA1c as normal HbA1c in an actual patient with diabetes. Reportedly, such false results can delay diagnosis, with a potential of poor outcomes in the long-term ${ }^{8}$. 
In this study, we aimed to determine the efficacy of $\mathrm{HbA} 1 \mathrm{c}$ alone in diagnosing type 2 diabetes by determining the relationship between glucose levels in OGTT and HbA1c in the Turkish population. We also aimed to review the diagnosis of diabetes mellitus by determining the time points at which glucose levels in a standard OGTT had a relatively better correlation with $\mathrm{HbA1c}$ and AUC.

\section{METHODS}

Subjects who presented with hyperglycemia at the Adult Outpatient Clinics of Dicle University Faculty of Medicine between 2010 and 2012 and underwent 75-g 0GTT were enrolled in this study. This study was approved by the Dicle University Ethics Committee (754/2012), and informed consent was obtained from the subjects before their enrolment. Patients with known diabetes, those who were receiving any oral antidiabetics or insulin, pregnant women, and patients with anemia or known hemoglobinopathy were excluded. According to glucose tolerance at the time of diagnosis, patients with a 2-hour plasma glucose level of $\geq 200 \mathrm{mg} / \mathrm{dL}$ in standard OGTT or FPG level of $\geq 126 \mathrm{mg} / \mathrm{dL}$ were considered diabetic according to the ADA criteria ${ }^{9}$.

In the standard OGTT, subjects were instructed to consume a normal carbohydrate diet for 3 days, followed by overnight fasting for 8-14 hours. Fasting blood samples were collected in the morning $(0 \mathrm{~min})$, and the subjects were asked to drink $75 \mathrm{~g}$ of glucose dissolved in 300 $\mathrm{mL}$ of water in 5 minutes. Plasma glucose levels were assayed at 120 minutes in all subjects and additionally at 30,60, and 90 minutes in subject who provided consent. HbA1c was measured using automatic Agilent 1100 device and BioSystems S.A. kits with the high performance liquid chromatography (HPLC) method.

\section{Statistical Analysis}

SPSS 18 software was used for data analysis. For statistical analysis of the data, continuous variables were expressed as mean and standard deviation and variables were expressed as number and percentage. Chi-square test was used to compare categorical data. Pearson's correlation coefficient was used to determine if there was a linear correlation between the measurements, and the receiver operating characteristic (ROC) curve was used to determine the sensitivity and specificity of the HbA1c cut-off values in diagnosing diabetes. The area under the curve (AUC) was calculated for plasma glucose levels. A $p$ value of $<0.05$ was considered statistically significant.

\section{RESULTS}

The study included 560 subjects: 363 (64.9\%) females and 197 (35.1\%) males. The mean age of the subjects was $46.7 \pm 12.9$ years (range 1584 years). Overall, 328 subjects underwent testing for blood glucose levels only between 0 and 120 minutes, where as the remaining 232 subjects underwent testing for blood glucose levels at $0,30,60,90$, and 120 minutes.

Among the 560 subjects, 129 (23\%) had diabetes $(114$ patients were diagnosed according to OGTT at 2 hours and 15 patients according to the FPG results) and 227 (40.5\%) had normal glucose tolerance. Among the subjects who underwent OGTT and blood glucose measurements at $0,30,60,90$, and 120 minutes, $40(17.3 \%)$ had diabetes and 112 $(48.3 \%)$ had normal glucose tolerance.

In subjects with diabetes, an HbA1c cut-off value of $\geq 6.5 \%$ yielded a sensitivity of $55.0 \%$, specificity of $80.9 \%$, positive predictive value (PPV) of $46 \%$, and negative predictive value (NPV) of $85 \%(\mathrm{P}<0.01)$ (Table 1$)$. 
Table I: Sensitivity and specificity of HbA1c cut-off values in diagnosing diabetes

\begin{tabular}{|c|c|c|}
\hline HbA1c (\%) & $\begin{array}{l}\text { Sensitivity (\%) } \\
\text { n=129 }\end{array}$ & $\begin{array}{l}\text { Specificity (\%) } \\
\mathbf{n}=129\end{array}$ \\
\hline 6.1 & 71.3 & 65.4 \\
\hline 6.5 & 55.0 & 80.9 \\
\hline 6.8 & 40.3 & 91.0 \\
\hline 7.0 & 31.0 & 95.1 \\
\hline 7.3 & 22.5 & 98.1 \\
\hline 7.6 & 15.5 & 100 \\
\hline
\end{tabular}

An HbA1c cut-off value of $\geq 6.5 \%$ in patients diagnosed with diabetes according to the 2hour OGTT yielded a sensitivity of $56 \%$, specificity of $80 \%$, PPV of $41 \%$, and NPV of $87 \%$ $(\mathrm{P}<0.01)$. According to the ROC curve, the sensitivity and specificity of an optimal HbA1c cut-off value of $6.1 \%$ in diagnosing diabetes were $71.3 \%$ and $65.4 \%$, respectively (Figure 1 ).

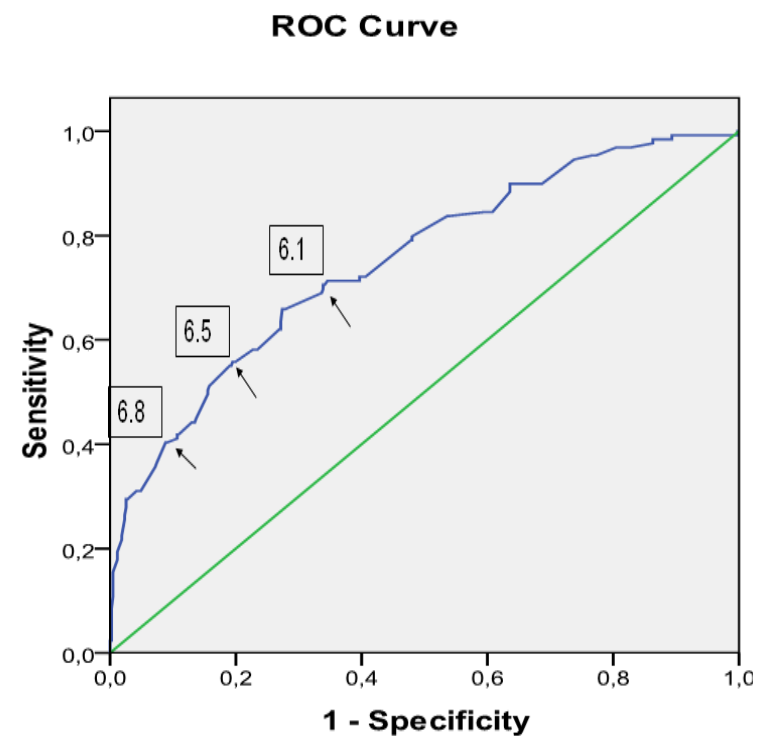

Figure 1: ROC curve in diabetes diagnosis. HbA1c cut-off values of $6.1,6.5$, and 6.8 are shown on the curve.

HbA1c is $<6.5 \%$ in $43.8 \%$ of the patients with diabetes according to OGTT and $\geq 6.5 \%$ in $13.7 \%$ of the patients with normal glucose tolerance in OGTT (Table 2).

Table II: The relationship between glucose tolerance in OGTT and $\mathrm{HbA} 1 \mathrm{c}$

\begin{tabular}{|c|c|c|}
\hline HbA1c (\%) & NGT & Diabetes \\
\hline$<\mathbf{5 . 7}$ & $96(42.3 \%)$ & $\mathbf{n = 1 1 4}(\mathbf{2})$ \\
\hline $\mathbf{5 . 7 - 6 . 4}$ & $100(44 \%)$ & $12(10.53 \%)$ \\
\hline $\mathbf{2 6 . 5}$ & $31(13.7 \%)$ & $38(33.33 \%)$ \\
\hline
\end{tabular}

OGTT: Oral glucose tolerance test, HbA1c: Hemoglobin A1c, NGT: Normal glucose tolerance

AUC and HbA1c showed the highest correlation with 90-minute glucose levels in OGTT $(\mathrm{r}=0.971$ and $\mathrm{r}=0.464$, respectively; $\mathrm{P}<0.01$ ) (Table 3 ).

Table III: The correlation between plasma glucose levels in OGTT and HbA1c, AUC

\begin{tabular}{|c|c|c|}
\hline & HbA1c & AUC \\
\hline $\begin{array}{l}\text { OGTT at } 0 \mathrm{~min} \\
(\mathrm{n}=560)\end{array}$ & $\begin{array}{c}r=0.379^{*} \\
P<0.01\end{array}$ & $\begin{array}{r}r=0.778^{*} \\
P<0.01\end{array}$ \\
\hline $\begin{array}{l}\begin{array}{l}\text { OGTT at } 30 \\
\text { minutes } \\
(n=232)\end{array} \\
\end{array}$ & $\begin{array}{c}r=0.388^{*} \\
P<0.01\end{array}$ & $\begin{array}{r}r=0.823^{*} \\
P<0.01\end{array}$ \\
\hline $\begin{array}{l}\begin{array}{l}\text { OGTT at } 60 \\
\text { minutes } \\
(n=232)\end{array}\end{array}$ & $\begin{array}{c}r=0.427^{*} \\
P<0.01\end{array}$ & $\begin{array}{r}r=0.952^{*} \\
P<0.01\end{array}$ \\
\hline $\begin{array}{l}\begin{array}{l}\text { OGTT at } 90 \\
\text { minutes } \\
(n=232)\end{array}\end{array}$ & $\begin{array}{c}r=\mathbf{0 . 4 6 4}^{*} \\
P<0.01\end{array}$ & $\begin{array}{r}r=\mathbf{0 . 9 7 1}^{*} \\
P<0.01\end{array}$ \\
\hline $\begin{array}{l}\text { OGTT at } 120 \\
\text { minutes } \\
(n=560)\end{array}$ & $\begin{array}{c}r=0.442^{*} \\
P<0.01\end{array}$ & $\begin{array}{l}\mathrm{r}=0.895^{*} \\
\mathrm{P}<0.01\end{array}$ \\
\hline
\end{tabular}




\section{DISCUSSION}

Evaluation of HbA1c has become common in routine practice as a diagnostic test for diabetes considering the global efforts to standardize HbA1c and the increasing amount of evidence, indicating its prognostic value. In this study, we investigated the efficacy of HbA1c in diagnosing type 2 diabetes. The first important finding of our study was that an HbA1c cut-off value of $6.5 \%$ had relatively low sensitivity. Comparison of the patients diagnosed with diabetes according to OGTT with an HbA1c cut-off value of $6.5 \%$ showed a sensitivity and specificity of $56 \%$ and $80 \%$, respectively. The Rancho Bernardo study reported that an HbA1c cut-off value of $6.5 \%$ in 2017 participants showed similar results with a sensitivity of $44 \%$ and specificity of $79 \%{ }^{10}$. Although the results of these studies were similar to those of our study, we also observed that an HbA1c cut-off value of $6.5 \%$ had low sensitivity in diagnosing diabetes and that the specificity values of HbA1c were lower in our study than in most of the previous studies $6,7,11-16$. Further multicenter studies with a larger sample size are warranted to assess whether HbA1c is a satisfying parameter in the diagnosis of diabetes. Evaluations of HbA1c can lead to the misdiagnosis of diabetes or delay the diagnosis due to its limited sensitivity ${ }^{10}$. Therefore, the diagnostic efficacy of HbA1c remains controversia6,17.

Although $\mathrm{HbA1c}$ is a fast and useful test, another diagnostic test may be required to confirm the diagnosis of diabetes in some cases. It is also important to consider the factors that can affect hemoglobin glycosylation independent of the glycemic status, including sex and race/ethnicity 3 . In cases when these conditions are present and interpretation of HbA1c values is challenging, the diagnosis of diabetes should be based on conventional glucose measurements. It may be quite premature to consider $\mathrm{HbA1c}$ as a substitute for OGTT $^{6}$. Despite a strong correlation between $\mathrm{HbA1c}$ and OGTT, these tests may sometimes produce inconsistent results; therefore, it was assumed that OGGT and HbA1c reflect different categories of dysglycemia ${ }^{13}$.

HbA1c has a lower sensitivity in diagnosing diabetes than FPG or plasma glucose levels at 2 hours ${ }^{6}$. In our study, it was observed that the diagnosis of diabetes could be missed using an HbA1c cut-off value of $\geq 6.5 \%$ in $43.8 \%$ of the patients who had diabetes according to OGTT. Some studies have reported a false negative rate of $68.4 \%^{6}, 66.8 \%{ }^{11}$ and $48.7 \%^{12}$ in diagnosing diabetes. According to World Health Organization (WHO), a significant number of individuals cannot be diagnosed with diabetes using only an HbA1c cut-off value of $6.5 \%$ and that a probable diagnosis of diabetes can be made using an HbA1c cut-off value of $\geq 7.5 \% 18$. In the Turkish population, an HbA1c cut-off value of $\geq 7.6 \%$ does not require additional tests and re-evaluation for confirming the diagnosis of diabetes. On the other hand, OGTT can be considered in patients with HbA1c values $<7.6 \%$ to avoid misdiagnosis. Accordingly, some researchers still consider that OGTT is necessary to confirm the diagnosis ${ }^{16}$.

The majority of patients with diabetes are reportedly left undiagnosed ${ }^{14}$; moreover, microvascular and macrovascular complications can be present at the time of diagnosis ${ }^{15}$. Therefore, early diagnosis has critical importance in preventing and managing diabetes ${ }^{12}$. It was confirmed that a 2 -hour plasma glucose level in OGTT was able to diagnose more subjects with diabetes than FPG and HbA1c cut-off values ${ }^{3}$. Based on the OGTT results, approximately $10 \%$ of the patients with diabetes could not be diagnosed with diabetes according to their 2-hour plasma glucose levels ${ }^{19}$. In our study, $11.6 \%$ of the patients with diabetes could not be diagnosed using the 2hour plasma glucose levels according to the ADA criteria9. 
Considering the AUC and prediabetic period and that the path that leads to diabetes diagnoses has four steps, it is possible to say that the first step is impaired fasting glucose (IFG), the second step is impaired glucose tolerance (IGT), the third step is combined IFG/IGT, and the fourth step is diabetes. Early detection of prediabetic conditions seems to be the suitable approach to prevent the development of diabetes. AUC was proposed as a predictive method for determining the risk of diabetes and prediabetes. It was emphasized that the use of glucose values only was not sufficient to reflect the risk of diabetes and that 60,75 , and 90 minutes were considered as the time points that could best determine the glucose load and AUC $^{20}$. It was found that AUC is very sensitive and specific for diabetes, IGT, and risk of developing diabetes groups and that AUC has better correlation with 1-hour glucose level21. In frequent glucose measurements, glucose levels at 60 and 90 minutes were reported to be better indicators than glucose levels at 120 minutes ${ }^{22}$. Alyass et $\mathrm{al}^{23}$ have reported that the 1-hour plasma glucose level was a valuable predictive measure in identifying adults at risk for type 2 diabetes. Abdul-Ghani et al. have associated 1-hour plasma glucose level with a markedly enhanced prediction of type 2 diabetes $^{24-26}$ and a significant increase in the incidence of diabetes ${ }^{27}$. In addition, the 1-hour plasma glucose level was suggested as a tool to identify individuals with type 2 diabetes in San Antonio Heart and Botnia studies ${ }^{28}$. Other studies have also discussed the use of 1-hour plasma glucose as an important indicator of type 2 diabetes 29,30 . Our study showed that plasma glucose levels at 90 minutes had better correlation with AUC and HbA1c than plasma glucose levels at other time points. It would be beneficial to investigate whether plasma glucose at 90 minutes is a more important parameter in predicting diabetes. Indeed, it can be a better indicator of diabetes.
In conclusion that we conclude HbA1c does not have sufficient sensitivity and specificity in diagnosing diabetes. Because plasma glucose levels at 90 minutes in OGTT showed the best correlation with both AUC and HbA1c, it can be considered a more suitable parameter for diagnosing diabetes instead of 2-hour plasma glucose as it can save time compared with the standard OGTT. More extensive studies evaluating the efficacy of evaluating plasma glucose levels at 90 minutes in diagnosis of diabetes are warranted.

Ethics Committee Approval: This study was approved by the Dicle University Ethics Committee (754/2012), and informed consent was obtained from the subjects before their enrolment.

Declaration of Conflicting Interests: The authors declare that they have no conflict of interest.

Financial Disclosure: No financial support was received.

\section{REFERENCES}

1. American Diabetes Association. Diagnosis and classification of diabetes mellitus. Diabetes Care. 2011; 34 (Suppl.1): 62-9.

2. American Diabetes Association. 6. Glycemic Targets: Standards of Medical Care in Diabetes. Diabetes Care. 2018; 41 (Suppl.1): 55-64.

\section{American Diabetes Association. 2.}

Cassification and Diagnosis of Diabetes:

Standards of Medical Care in Diabetes.

Diabetes Care. 2018; 41(Suppl.1): 13-27

4. International Expert Committee report on the role of the A1c assay in the diagnosis of diabetes: Diabetes Care. 2009; 32: 1327-34.

5. American Diabetes Association. Standards of Medical Care in Diabetes. Diabetes Care. 2010; 33 (Suppl.1): 11-61. 
6. Lages MV, Lauria MW, Goncalves Dias AP, et al. Can A1Creplace oral glucose tolerance test in the evaluation of patients with impaired fasting glucose? EndocrinolMetabIntJ. 2017; 4: 133-9.

7. Ramachandran A, Snehalatha C, SamithShetty A, et al. Predictive value of $\mathrm{HbA1c}$ for incident diabetes among subjects with impaired glucose tolerance-analysis of the Indian Diabetes Prevention Programmes. Diabet Med. 2012; 29: 94-8.

8. d'Emden MC. Glycatedhaemoglobin for the diagnosis of diabetes. AustPrescr.

2014;37:98-100.

9. American Diabetes Association. Standards of Medical Care in Diabetes. Diabetes Care. 2007; 30(Suppl.1): 4-41.

10. Kramer CK, Araneta MR, Barrett-Connor E. A1C and diabetes diagnosis: The Rancho Bernardo Study. Diabetes Care. 2010; 33(1): 101-3.

11. Yu EY, Wong CK, Ho SY, et al. Can HbA1c replace OGTT for the diagnosis of diabetes mellitus among Chinese patients with impaired fasting glucose? FamPract. 2015; 32: 631-8. 12. Xu N, Wu H, Li D, et al.Diagnostic accuracy of glycated hemoglobin compared with oral glucose tolerance test for diagnosing diabetes mellitus in Chinese adults: a meta-analysis. Diabetes Res CinPract. 2014; 106: 11-8.

13. Meijnikman AS, De Block CEM, Dirinck E, et al. Not performing an OGTT results in significant underdiagnosis of (pre)diabetes in a high risk adult Caucasian population. Int J Obes (Lond). 2017; 41: 1615-20.

14. Adamska E, Waszczeniuk M, GościkJ, et al. The usefulness of glycated hemoglobin A1c (HbA1c) for identifying dysglycemic states in individuals without previously diagnosed diabetes. Adv Med Sci. 2012; 57: 296-301.

15. Silverman RA, Thakker U, Ellman T, et al.Hemoglobin A1c as a screen for previously undiagnosed prediabetes and diabetes in an acute-care setting. Diabetes Care. 2011; 34: 1908-12.

16. Van 'tRiet E, Alssema M, Rijkelijkhuizen JM, et al. Relationship between A1Cand glucose levels in the general Dutch population: the new Hoorn study. Diabetes Care. 2010; 33: 61-6.

17. Kim HJ, Choi EY, Park EW, et al. The Utility of $\mathrm{HbA1} \mathrm{c}$ as a Diagnostic Criterion of Diabetes. Korean J Fam Med. 2011; 32: 383-9.

18. Manley S, Nightingale P, Stratton I, et al. Diagnosis of diabetes: $\mathrm{HbA1}$ c versus WHO criteria. Diabetes \& Primary Care. 2010; 12 : 87-96.

19. Kim SH, Park TS, Jin HY. Rethinking the accuracy of $75 \mathrm{~g}$ glucose used in the oral glucose tolerance test in the diagnosis and management of diabetes. Prim Care Diabetes. 2017; 11: 555-60.

20. Kjøllesdal MKR, Hjellset VT, Høstmark AT. Blood glucose measured at several time points and correlation with incremental area under the curve.J Nutr Food Sci. 2014; 4: 315.

21. Sakaguchi K, Takeda K, Maeda M, et al.Gucose area under the curve during oral glucose tolerance test as an index of glucose intolerance. Diabetol Int. 2015; 7: 53-8.

22. Nielsen ML, Pareek M, Leósdóttir M, et al.Follow-up duration influences the relative importance of OGTT and optimal timing of glucose measurements for predicting future type 2 diabetes. Eur J Endocrinol. 2016; 174: 591-600.

23. Alyass A, Almgren P, Akerlund M, et al. Modelling of OGTT curve identifies $1 \mathrm{~h}$ plasma glucose level as a strong predictor of incident type 2 diabetes: results from two prospective cohorts. Diabetologia. 2015; 58: 87-97.

24. Abdul-Ghani MA, Williams K, DeFronzo RA, et al. What is the best predictor of future type 2 diabetes? Diabetes Care. 2007; 30: 1544-8. 
25. Abdul-Ghani MA, Lyssenko V, Tuomi T, et al. Fasting versus postload plasma glucose concentration and the risk for future type 2 diabetes: results from the Botnia Study. Diabetes Care. 2009; 32: 281-6.

26. Abdul-Ghani MA, Abdul-Ghani T, Ali N, et al. One-hour plasma glucose concentration and the metabolic syndrome identify subjects at high risk for future type 2 diabetes. Diabetes Care. 2008; 31: 1650-5.

27. Abdul-Ghani MA, Stern MP, Lyssenko V, et al.Minimal contribution of fasting hyperglycemia to the incidence of type 2 diabetes in subjects with normal 2-h plasma glucose. Diabetes Care. 2010; 33: 557-61.
28. Abdul-Ghani MA, Abdul-Ghani T, Stern MP, et al. Two-step approach for the prediction of future type 2 diabetes risk. Diabetes Care. 2011; 34: 2108-12.

29. Kuang L, Huang $Z$, Hong $Z$, et al. Predictability of 1-h postload plasma glucose concentration: A 10-year retrospective cohort study. J Diabetes Investig. 2015; 6: 647-54.

30. Peddinti G, Bergman M, Tuomi T, et al. 1Hour Post-OGTT Glucose Improves the Early Prediction of Type 2 Diabetes by Clinical and Metabolic Markers. J Clin Endocrinol Metab. 2019; 104: 1131-40. 